\title{
Sappho and the Mythopoetics of the Domestic
}

\author{
Anastasia-Erasmia Peponi
}

In San Francisco's Palace of the Legion of Honor one can enjoy a typical work by Pieter de Hooch, a leading painter of the so-called Delft School and the Dutch Golden Age. The painting, entitled A Woman Nursing an Infant with a Child and a Dog, depicts one of the serene domestic scenes the Delft School is well-known for having repeatedly celebrated, especially around the middle of the seventeenth century (Fig. 10.1). It is a domestic interior, with a woman sitting by a window, where soft, glowing light comes in. Unlike his contemporary Vermeer, whose domestic settings with women sitting or standing by a window usually suggest a state of longing, Pieter de Hooch's nursing mother, with her infant in her lap and her other child beside her feeding a dog while catching a playful glimpse of the viewer, exudes blissful familial content.

No other representative of Dutch genre painting, with its renowned depictions of everyday life and predilection for interior settings, seems to have explored so persistently the pictorial possibilities not just of the domestic in general but of the familial more specifically. ${ }^{1}$ A large number of Pieter de Hooch's interiors are marked by the unmistakable presence of familial snapshots: children of various ages interacting with their mothers in different spots within the Dutch household. More than just a moral commentary on and confirmation of the Dutch bourgeois household with the nuclear family at its core, these pictures raise broader questions regarding the construction, proliferation, and potential of artistic discourses about the "actual" and the "real" in a given society. Thus de Hooch's distinctive interest in the familial may be seen as an attempt to further expand on the prevailing Dutch mentality of his day, which encouraged the contemplation of contemporary culture as reflected in the genre images it continually inspired.

From the point of view of a classicist interested in the production, circulation, and interpretation of lyric genres, such phenomena in the history of cul-

1 On the domestic in Pieter de Hooch's works, see esp. Sutton (1998) 30-31 and 68-75. From the rich literature on Dutch genre painting Todorov (1997) 9-41 and Schama (1997) $375^{-562}$ are particularly relevant to the aspects briefly discussed here.

(C) ANASTASIA-ERASMIA PEPONI, 2016 | DOI: 10.1163/9789004314832_012

This is an open access chapter distributed under the terms of the Creative Commons Attribution-

Noncommercial 3.0 Unported (CC-BY-NC 3.0) License. 


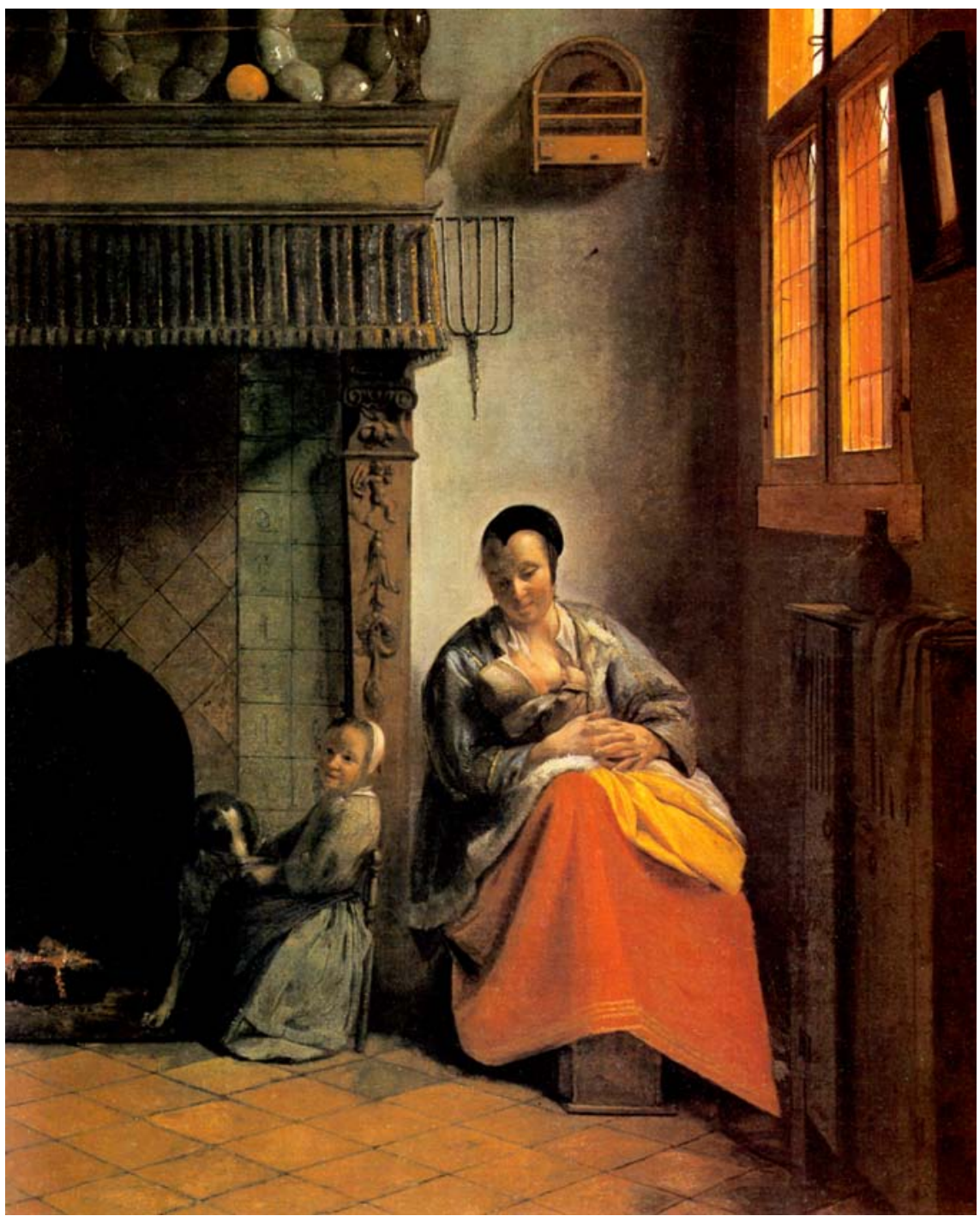

FIGURE 10.1 Painting of Pieter de Hooch. Interior with mother breast-feeding and child, 1658-1660. Oil on canvas, $68 \times 56 \mathrm{~cm}$.

M.H. YOUNG MEMORIAL MUSEUM, SAN FRANCISCO. IMAGE RESEARCH: CENTRUM VOOR KUNSTHISTORISCHE DOCUMENTATIE, RADBOUD UNIVERSITY.

ture are significant. Despite the obvious historical divergences between archaic Greece and Golden Age Holland, the taste of both eras for discourses (verbal in the former case, visual in the latter) involving the representation of what appears to be the current reality is noteworthy, especially if one takes into 
account the fact that in both cases preexisting, well-established art was engaging with larger, heroic or religious, mythological themes.

Hence Pieter de Hooch's fascination with the familial provides a tempting comparative stimulus when one contemplates how Sappho's poems that presumably refer to her brothers may have been culturally vital in her times. For among the lyric poets of the archaic period who favored compositions anchored in the so-called hic et nunc (the alleged current reality in which the first-person speaker appears), Sappho seems to have experimented eagerly with the potential presented by a poetics of the familial. Such an approach would explain not only the cluster of poems relating to her brothers, but also poems where she seems to have referred to her own daughter. ${ }^{2}$

Questions about the correlation between the production and consumption of artistic discourses in a given period are of importance here. If in the Dutch Golden age a tranquil, domestic scene by Pieter de Hooch had the soothing effect of cultural self-assurance for a contemporary viewer, while also suggesting the tremendous aesthetic potential hidden in the most banal aspects of the mundane, how are we to think about the cultural consumption of a poem by Sappho in the archaic period, revolving around her brothers? To raise the question more specifically in regards to the recently published papyrus, why would an audience on Lesbos or elsewhere enjoy listening to a poetic dialogue that, far from evoking generic familial coziness, brims with a very specific type of familial crisis apparently induced by the delayed nostos of one brother and the lingering maturation of another? What might have been the cultural premises behind Sappho's confidence that such discourses about one's own domestic calamities and struggles are a valuable poetic enterprise, attractive to contemporary listeners?

There are two underlying and interrelated issues in question. First, the manner in which audiences in a given period, spectators or listeners, may associate with and enjoy visual or verbal representations depicting an artist's current reality; and, second, the manner in which such expectations on the part of audiences both shape and are shaped by the representational modes employed by the artists themselves. To return to the visual poetics of the familial as practiced in Pieter de Hooch's work, the consensus is that the figures in his domestic settings would have been perceived by his viewers as generic personae and not as persons with individual biographical identities, despite

2 For references to her daughter, Kleis, see fr. $98 \mathrm{~b}$ and fr. 132. See also Hallett (1982) 21-31. For other poems relevant to her brothers, see fragments $5,7,15$ and most probably 3 . See also Lardinois, this volume. 
the fact that the painter might have used actual members of his own family as models for his work. ${ }^{3}$ This strategy of underplaying individual identity while at the same time glorifying contemporary reality was, of course, typical of Dutch genre painting in general. It probably facilitated a mechanism of abstraction on the part of viewers, whereby the essentials of the real, its hidden eternals, could be grasped and contemplated promptly. Thus, looking at Pieter de Hooch's $A$ Woman Nursing an Infant with a Child and a Dog, far from arousing a viewer's curiosity about a potential invisible story behind the visible figures, would instead instill an apprehension of the overall sensuousness of the scene that, even though it is inherent in the actual domestic routine, can be most fully disclosed through the tranquility of pictorial representation.

The representational strategies of the "current" and the "real" in Greek lyric poetics differ, however, for here named figures, meant to be perceived as existing contemporaries of the first-person lyric speakers, inhabit a large part of this poetry. ${ }^{4}$ This is a distinctive mechanism of early Greek lyric which, as is wellknown, proved to be quite durable in the centuries to come, not only in the many transformations of Greek lyric poetry but in Roman lyric poetics as well. It is reasonable to imagine that its intended tenor of specificity affected the formation of audiences' expectations and the registers of apprehension and enjoyment, both of which were linked to its key role in the construction of lyric mythopoetics.

While several such named figures appear as second-person addressees restricted to the beginning of a poem, there are other cases where they become part of a peculiar lyric mise-en-scène. It seems that Sappho was very interested in the potential of such compact scenes made to sound like parts of an ongoing larger narrative stemming from her current environment. A most illuminating instance is the quite complex mise-en-scène of fragment 96 that involves Atthis. ${ }^{5}$ It is helpful to focus briefly on this fragment as it presents us with a good example of a "staging" strategy, variations of which Sappho repeatedly favored in her poetry and that can be quite illuminating in the case of the newest Broth-

3 On this issue, see esp. Sutton (1998) 30.

4 Proper names such as Pericles, Glaukos, Melanippos, Bycchis, Agesilaides, Kleoboulos, Euryalos, are encountered in Archilochus', Alcaeus', Anacreon's and Ibycus' poetry, not to mention Theognis' much discussed fondness for Kyrnos. See respectively Archilochus frs. 7, 56; Alcaeus frs. 38, 1308, 335; Anacreon frs. 357, 359; Ibycus fr. 288; Theognis esp. 19-26 and throughout the corpus. Naming, as opposed to non-naming or mixed strategies in Sappho's and other lyric poetry, is an illuminating aspect of lyric poetics beyond the limits of this paper.

5 Atthis is mentioned in frs. 49, 96, 130. The name also seems to appear in frs. 8 and god (10a) 15. See also fr. 214C Campbell. 
ers Poem: triangular arrangements. Here a first-person speaker and a secondperson listener are fixed in the "hic" while, on the other hand, there is an absent and much longed for third woman in the far "illic", imagined as suffering from a reciprocal longing for the other two. By the end of the fragment one realizes that the eventually named Atthis plays the role of the second-person listener while also being presented as the marked object of longing for the woman stranded in a distant land (most probably—and quite specifically—Lydia). In other words, as Ezra Pound rightly sensed in his own modernist Sapphic snippet, Atthis probably appeared in several Sapphic poems as one of the poet's peculiar lyric characters, half-palpable in her specific traits and half-evanescent in her figurative role as an object of desire. ${ }^{6}$

My claim is that the recently published Brothers Poem not only presents us with what looks like a variation on the triangular mise-en-scène (here we have a first-person speaker, a second-person listener, and a situation caused principally by the absence of brother Charaxos that eventually prompts a reference to brother Larichos as well) but also - and more importantly-it gestures towards a similar, if more outstanding, register of specificity. ${ }^{7}$ In such cases, then, we have named figures who appear as originating from specific circumstances within the first-person speaker's real world while at the same time they are part of narrative strategies that retain, spotlight, or blur traits of personal identity according to their own representational economies.

I am employing the term "lyric mythopoetics" in order to capture precisely these peculiar narratives that appear to emanate from the present spatiotemporal coordinates of the first-person speaker, the lyric hic et nunc. Though such narratives do not always involve figures other than the first-person speaker, their mythopoetic power can be sensed more clearly whenever they do so. Despite their prominent spatiotemporal anchoring these narratives are autonomous verbal representations, detachable from their real or simulated original context and bearing a strong imaginary potential. Hence their perpetually oscillating status, sometimes as records of reality, other times as constructs of fiction. In fact, they may participate in both worlds at the same time, for their success lies in their capacity to reimagine the real in line with the economies of the verisimilar. ${ }^{8}$

6 See fr. 49. For Ezra Pound's modernist snippet inspired by Sappho's Atthis, see I $\mu$ źpp $\omega$, Poems of Lustra (1913-1915) in Pound (1990) 116.

7 Here I am interested in the Sapphic triangular mise-en-scène beyond her much discussed erotic triangle in fr. 31, for which see esp. Carson (1986) 12-13, 78-79, 86 and passim.

8 For a different approach to the concept of mythopoetics, see Bierl (2007a). 
I will return to the particulars of these alternative mythopoetic practices, which must have been crucial in molding the broader cultural mindset within which poems such as the one recently discovered were circulating. For now, it is important to investigate further the specific premise with which I started. In an era that was generally attentive to the poetic transformations of the "real", what other factors could have contributed to Sappho's interest in the mythopoetic potential of one's own familial stories? Since the bulk of available evidence in Sappho's poetry, including the latest find, indicates a richer production of one particular aspect of the familial, namely relationships between siblings as experienced from the viewpoint of a sister, it is useful to think of other sisterly discourses that were likely available to both Sappho and her audiences in some form or another.

Certainly, in larger epic narratives such as the Odyssey or, later, in drama parental relationships were foundational. Next to, or inside, such grand narratives, however, one encounters smaller instances with less grandeur but delightful lightness, such as that in Book 6 of the Odyssey where Nausicaa, in a rare moment of peaceful domesticity in Homeric epic, runs from her bedroom through the house to find her parents performing their everyday morning tasks (her mother by the fireside with the women weaving and her father ready to step out the door to go to the council) and says (6.57-65):

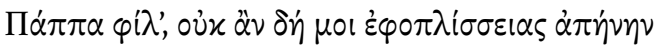

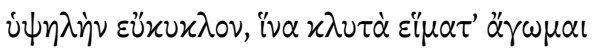

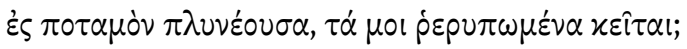

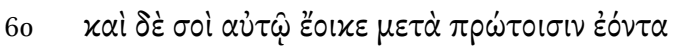

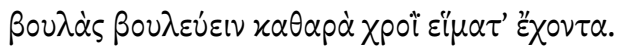

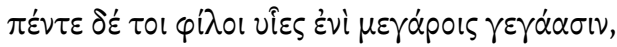

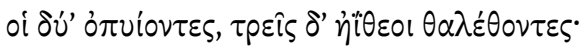

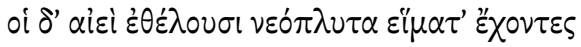

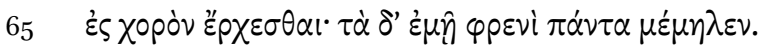

Daddy dear, will you not have them harness me a wagon, the high one with the good wheels, so that I can take the clothing to the river and wash it? Now it is lying about, all dirty,

6o and you yourself, when you sit among the first men in council and share their counsels, ought to have clean clothing about you; and also, you have five dear sons who are grown in the palace, two of them married, and the other three are sprightly bachelors, and they are forever wanting clean fresh clothing, to wear it

65 when they go to dance, and it is my duty to think about this.

Translation by R. LATTIMORE 
This moment is indeed relevant to the present discussion. For here the cutely lying young Nausicaa, excited by the prospect of her own marriage, feigns concern not just about her father's dirty clothes but also about those of her bachelor brothers in case they need to go to dance-dance being here a metonymy for courting and eventually marriage. Not many times in Greek literature is one made to think about the domestic occasions in which sisters would step into and even manipulate the romantic prospects of their brothers. No matter how parenthetical and lighthearted Nausicaa's reference to her brothers' potential courtship is here, it reminds us that Sappho's saga about her brother Charaxos' romantic life would indeed belong to this background of domestic concerns and debates.

Such familial matters, along with their quite prominent gender aspect, bring to mind the case of another female author-quite distant from Sappho in time and space-Jane Austen. All sorts of intrigues involving sisters and brothers are key to her plots, yet several of these episodes were indeed transformations of her own experiences as a sister, especially in Mansfield Park and Persuasion. As early as $1906 \mathrm{John}$ and Edith Hubback published a book entitled Jane Austen's Sailor Brothers - a title, of course, particularly suggestive in light of the newest poem about Sappho's sailor brother. It is a thorough study of various sources, mainly letters, which show how Jane Austen's sailor brothers, Sir Francis Austen, Admiral of the Fleet, and vice-admiral Charles Austen, permeated the sisters' life-sisters here in plural for we know that Jane and Cassandra were frequently exchanging notes and letters about their brothers. The book also shows how "real" episodes described or alluded to in these letters are transferred to and transformed in Jane Austen's novels. Serious concerns about the brothers' prolonged absences and gossip about their intermittent periods of presence and romance are recurrent themes in the sisters' written exchanges. ${ }^{9}$

Unfortunately, we hear nothing about a sister of Sappho-the secondperson addressed in the recent poem (quite possibly a woman) is probably not the equivalent of the Cassandra figure in Jane Austen's life. ${ }^{10}$ And, in any case, we should not be looking for perfect symmetries. Yet for a modern reader, Jane Austen's case, with its dim and indirect but existing correspondences between the real world of a sister and the fictional one, offers yet another interesting lens through which to detect (and distinguish) Sappho's recently published poem.

Hubback and Hubback (1906) esp. 1-14, 49-51, 91-93, 94-110.

10 For a female figure as Sappho's addressee in the brothers-poem, see Obbink (2014b) 41, as well as Obbink, ch. 9, and Kurke in this volume. 
Another passage from Greek poetry, a quite famous one from Aeschylus' Libation Bearers (235-243), presents an illuminating case of sisterly discourse:

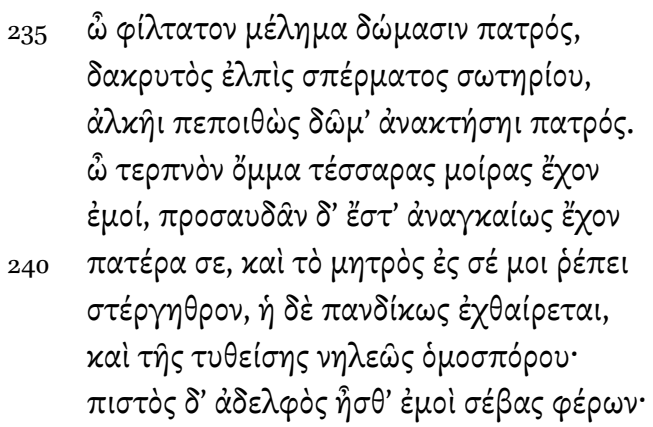

Dearest one [philtaton melêma], treasure of your father's house! The seed we wept for, in the hope it would sprout and save us! O joyful light, as you fill four roles for me. I must needs address you as father, and the affection I owe to a mother falls to you - for her I hate, with every justification - and also that of the sister who was pitilessly sacrificed; and you were a faithful brother, the only person who has shown me respect.

\section{Trans. A.H. SOMMERSTEIN}

This is Electra, finally convinced that the young man before her eyes is her brother, Orestes, absent for a long time and now returning to take revenge for their father's death. Given the solemnity of the plot in Aeschylus' play, Electra's speech is ponderous but also bittersweet. The sweetness of her initial address, philtaton melêma, is particularly notable, melêma being a charged word expressing the disquieting concern that goes with loving someone.

Indeed, melêma is a word Sappho seems to have used, although we will probably never know if she ever employed it in relation to her own long-absent brother. ${ }^{11}$ Similarly, we might never learn if a reunion between her and her brother was ever part of her repertoire. I single out these two speeches, Nausicaa's and Electra's, because they are both uttered by young women displaying different aspects of sisterly concern and bringing up diverse but comparable facets of the domestic. The scene involving Nausicaa represents a moment of domestic routine; the scene involving Electra represents a moment of domes-

11 Sappho fr. 163. For a discussion of this term in Greek aesthetics, see Peponi (2012) 107114. 
tic collapse. For all their differences, they both demonstrate what seems to be a well-established and developed sisterly discourse in archaic and early classical ancient literature.

What is crucial for the point made here is Sappho's plausible familiarity with sisterly discourses in the established poetic repertory of her times, especially that associated with the epic cycle. ${ }^{12}$ For that matter, it is not at all necessary to assume that Nausicaa or Electra were her specific or only possible sources of inspiration, although it is reasonable to suppose that she was aware of and intrigued by both characters. As far as Nausicaa is concerned, it is not hard to imagine that versions of what we know as the Odyssey were in circulation in Lesbos. Moreover, Alcman, with whose poetic and cultural heritage Sappho must have been (directly or indirectly) in touch, is very likely to have elaborated on other aspects of Nausicaa's role, an additional and important detail to be considered in respect to Sappho's familiarity with her poetic profile. ${ }^{13}$ As for Electra, there seems to be unanimous consent that Aeschylus' famous anagnôrisis between the two siblings in the Libation Bearers was actually modeled upon a major lyric poet's work, Stesichorus, whose own Oresteia-probably a quite long lyric narrative-included a similar scene. ${ }^{14}$ Whether or not Sappho was a contemporary of Stesichorus, as the Suda states clearly and puzzlingly, is part of an ongoing debate regarding Stesichorus' floruit. ${ }^{15}$ Nonetheless, a link connecting and contrasting Sapphic and Stesichorean poetics would open up possibilities for numerous tempting hypotheses that cannot be pursued here. For our present purposes, though, it is important to note that a poetic version of the Oresteia story was very likely in circulation even before Stesichorus and was attributed to the poet Xanthus. ${ }^{16}$ Such evidence reinforces the possibility

12 For other aspects of Sappho as a sister, see Bierl, ch. 14, and Nagy in this volume.

13 For Nausicaa in Alcman, see esp. frs. 4A and 81. See also Brown (1978) 36-38. For the broader associations between Nausicaa and female choruses, see Calame (2001/1997) 31, 42, 87, and passim. For Sappho and Alcman, see for instance Nagy (1996) 7-103; Calame (2001/1997) 207-263; Stehle (1997) 262-318.

14 For another detail possibly connecting Sappho's poem with Electra's diction in Aeschylus' Libation Bearers, see Obbink (2014b) 42. On Stesichorus' Oresteia, see Davies and Finglass (2014) 488-491. For the anagnôrisis scene, see Davies and Finglass (2014) 508510.

15 For a slightly later chronology, see West (1971): contra Burnett (1988) 135. For a recent account of the debate, see Finglass in Davies and Finglass (2014) 1-6, whose conclusion on p. 6 indicates that Stesichorus' dates (with his career covering 'some of the period between $\left.610-540^{\prime}\right)$ might have indeed overlapped partially with Sappho's.

16 For Xanthus as a lyric poet predating Stesichorus and as the composer of an Oresteia, see 
that Sappho and her contemporaries could have been familiar with narratives engaging with Electra's profile as a sister.

Be that as it may, we can be quite confident that discourses about and by siblings were in circulation in Sappho's time, in established narratives including versions of the Trojan saga and especially the Nostoi. My suggestion so far has been that we can better understand the newest Sapphic discovery if we contextualize the first-person speaker's discourse about her brothers within this broader literary tradition of discourses about the domestic and, even more specifically, with sisterly logoi about and to brothers.

Yet unlike the stories of Nausicaa and Electra, who are promptly identifiable characters in established plots, Sappho's recently discovered poem seems to lack a straightforward narrative context. What we have here is a brief and unframed domestic vignette of probably no more than 6 or 7 stanzas. ${ }^{17} \mathrm{Sev}-$ eral external sources, on the other hand, as for instance those by Herodotus, Athenaeus, and Strabo, indicate that Sappho's repertoire involved not one but several poems relevant to her brothers and there are surviving Sapphic fragments that corroborate this fact. ${ }^{18}$ The possibility of recognizable lyric cycles in Sappho's repertory, involving shorter compositions that contained loose but perceptible thematic linkages, opens up a wide range of considerations. For our present purposes one ramification is particularly important: the ways in which such song cycles, a key instance of which is associated with the representation of the domestic, became an important part of Sappho's mythopoetics and played an important role in the conception of an alternative type of plotmaking.

In other words, the addition of the newest poem to the extant Sapphic corpus allows us to see with increased confidence how individual "lyric instantanés," "lyric snapshots," or "lyric vignettes" were meant to operate as distinct and self-standing facets of a narrative that was never explicitly organized as such. It was an implied, ex silentio longer narrative that never made its appearance as a continuum, as a Homeric-like plot with carefully arranged sequences of events. It is likely that this peculiar mythopoetics, with its technique of sculpting certain episodes like high reliefs in the midst of long, blank, chiselled backgrounds, was a poetics eagerly advanced by Sappho. This is a profoundly non-Aristotelian type of muthos. Contrary to what the philosopher would later

Athenaeus' testimony (fr. 699). Aelian also refers to Xanthus' earlier date and to some details of his rendering of Electra's myth (fr. 700). See Davies and Finglass (2014) esp. 484488 and $5^{08-510 .}$

17 See Obbink (2014b) 34 and ch. 9, this volume; Kurke, this volume.

18 See Lardinois, this volume. 
recommend in his discussion of tragedy, eliminating one episode would absolutely not affect the understanding and pleasure deriving from another. ${ }^{19}$ At the same time, because this mythopoetic model was clearly exploring the autonomy and efficacy of verbal representation while also displaying itself as rooted in a personally experienced reality, its reception was by definition open to a dual register. A number of sources throughout antiquity indicate that listeners and readers could appreciate a Sapphic vignette for its own artistry but would also be tempted to imagine it as part of underlying stories involving the poet herself. $^{20}$

Perhaps more than any other poem, or sets of poems, by Sappho, the recently published Brothers Poem prompts us to think about the compelling potential of this dual-reception-register as strongly encouraged by the poet's own mythopoetic strategies. Admitting this inherent duality might help us disentangle ourselves from such thoroughly and richly discussed disjunctions in the relevant scholarship as person vs. persona, biographical vs. poetic, personal vs. generic. ${ }^{21}$ Sappho's "mythopoetics of reality," with her "mythopoetics of the domestic" as its leading edge, suggests that this type of lyric invited its audiences to enjoy individual poems both as independent gems and as tesserae of a life-story mosaic. ${ }^{22}$ In doing this, it probably welcomed a synergy between poem and audience, whereby audiences played an active role in the formation and dissemination of the lyric imaginary surrounding a poem's circulation. It is likely that this lyric imaginary, while elaborating on the dormant links supposedly connecting Sappho's vignettes, often took the form of oral (and later compiled) exegetic scholia attached to the traveling poetry itself. And it is reasonable to believe, as well, that along with legitimate and perhaps authentic

19 Arist. Poet. 1450b-1451a; esp. 1451a27-35 in relation to Homeric muthos as a model for the tragic muthos.

20 On interpretive traditions focusing on Sappho's artistry, see for instance those reflected in the aesthetic appreciation expressed by literary critics such as Demetrius De eloc. esp. 127, 132, 166, Dionysius of Halicarnassus De comp. verb. 23.32-79, and Longinus De subl. 10.13. For the various biographical traditions associated with Sappho, esp. earlier ones, see for instance Lidov (2002) and Yatromanolakis (2007); see also Pitts (2002) for Sappho's biographical traditions throughout antiquity.

21 From the vast and important literature on this problem those more relevant to the present discussion are:Johnson (1982) esp. 1-75; Nagy (1990a) 339-381; Calame (1995) 3-57; Lardinois (1996); Kurke (2000) 58-87; Calame (2005) 1-16.

For a different approach see Miller (1994) esp. 51, 88, 99, who thinks that such implications 'of possible narrative relations' concerning the poetic ego first occurred in the first century BC with Catullus and the establishment of the collection. 
elements this lyric imaginary also incorporated alien fantasies. This latter possibility, however, should not obscure the fact that such proliferation of stories around Sappho and the figures of her poetry (most importantly those of her family and her brothers) was indeed encouraged by the dual-reception-register of her own mythopoetic practices.

Hence Sappho's "mythopoetics of the domestic" may have enhanced lyric sensibilities in two interrelated directions. On the one hand, like Pieter de Hooch in the Dutch Golden Age, Sappho is likely in her own era to have explored persistently the familial as an essential aspect of the representational potential inherent in one's own reality. On the other hand, with her detachable vignettes, themselves flashes of an underlying but rarely ever articulated storyline, she emulated established mythological treatments of the familial as these were shaped principally in the heroic narratives of her times. Her own "lyric mythopoetics" suggested that not only can one's real life be successfully re-imagined as part of a different yet equally important narrative; it can also be molded and thus shared in alternative yet equally enjoyable manners. We will never know if Sappho was familiar with the version of the Odyssey that came down to us, where the idea that one's own life can be contemplated in the world of song and that a listener may thoroughly apprehend his own representation in a skillfully structured narrative is persistently examined through Odysseus' character. ${ }^{23}$ Nevertheless, her own mythopoetics, and especially her "mythopoetics of the domestic", suggest a possible way in which the trivialities of the ordinary and the concerns of the mundane may have an equal share in the world of representation. Within this world, they can establish their own conceptualizations and modalities of aesthetic experience. ${ }^{24}$ If considered this way, then Sappho's and Pieter de Hooch's explorations into the domestic can indeed be mutually thought-provoking, despite their evident differences.

An Oxyrynchus papyrus dated to either the 1st or 2nd century AD and clearly relevant to Sappho's domestic themes can serve as a reassuring but also intriguing epilogue to our discussion: ${ }^{25}$

23 On this issue and its representation in the Odyssey see Peponi (2012) with further bibliography.

24 Considered this way Sappho's mythopoetics and especially her "mythopoetics of the domestic," with its explorations of the representational potential that underlies one's own reality, should be distinguished from modernist lyric and its interest in creating "masks" of the self. On this modernist anxiety see for instance Bates (1985) esp. 91-92 and Ellmann (1978) 174-179.

Test. 213A h (P.Oxy. 2506 fr. 48, col. iii, $36-48)=$ test. 14 Campbell. 


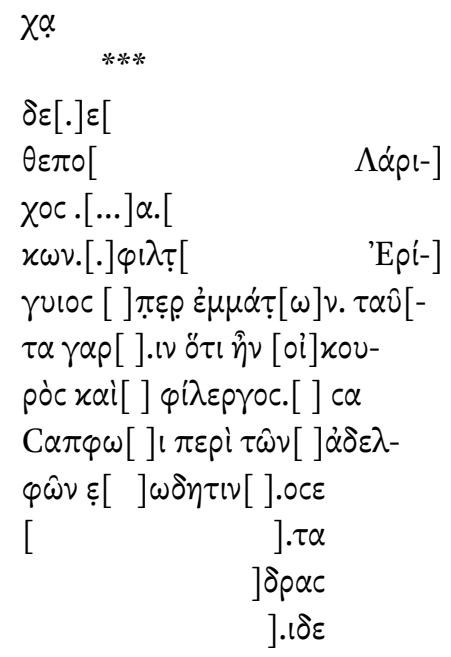

Cha(raxus?) ... (Lari)chus ... dearest ... (Eri)gyius for his clothes ( $\pi \varepsilon p$ $\varepsilon \mu \mu \alpha \dot{\alpha} \tau[\omega] \nu)$. This (shows?) that she was a good housekeeper and industrious. (As?) Sappho (says) in a poem about her brothers ...

Trans. D.H. CAMPBELL

We have here a snippet of both a Sapphic poem (the Aeolic form $\pi \varepsilon \rho_{p} \varepsilon \mu \mu \alpha \dot{\alpha} \tau[\omega] \nu$ leaves no doubt that these were lines of an actual poem) and an exegetic comment, the latter interpreting the former. On the one hand, the scene in the poem seems to revolve around somebody's clothes, most likely clothes belonging to Erigyios, though in all probability the other two brothers are named in the same context. On the other hand, the ancient commentator seems to be preoccupied with acknowledging or emphasizing Sappho's (or her brother's?) housekeeping efficiency, thus reminding us of the various ways in which ancient listeners and readers might have engaged with Sappho's "domestic mythopoetics" on the level of its alleged factual data. For us, however, the fragmented scene along with the fragmented comment carries subtle reminiscences of Nausicaa's feigned interest in her unmarried brothers' dirty clothes. If so, it serves as one more incentive to think about the manner in which Sappho might have been responding to established narratives while creating her own, thus prompting her audiences to reflect on the mythopoetic potential of their own most trivial concerns. $^{26}$

26 This paper is an expanded version of a talk delivered at Berkeley, in May 2014, and in Basel, Switzerland, in June 2014. Many thanks to Toni Bierl and André Lardinois for their suggestions and to Karen Bassi, Deborah Boedeker and Richard Martin for their comments. 